\title{
MAPPING THE LEGAL LANDSCAPE: CHINESE STATE-OWNED COMPANIES IN AUSTRALIA
}

\author{
Roman Tomasic ${ }^{*}$ and Ping Xiong**
}

\begin{abstract}
Australia has always relied heavily upon foreign sources of investment and financing and has in the past tended to draw mainly upon British, American and Japanese investment. In recent decades, Chinese state-owned enterprises (SOEs) have played an increasingly important role in the Australian economy with a rising level of investment taking place. Chinese SOEs have been more heavily involved in investments into larger Australian investment projects, such as in mining and infrastructure. Australia has seen an increase in the number of Chinese state-owned companies acquiring substantial domestic assets; this may continue following the ratification of the ChinaAustralia Free Trade Agreement in 2015. Although Chinese SOEs operating in foreign countries such as Australia are required to comply with local corporate governance laws and principles, they also retain their unique Chinese corporate governance values and culture which they have inherited through their parent companies and from China itself. In Australia, there has been an ongoing debate over Chinese investment, with the business community being particularly supportive of such investment. Driven largely by the business community, this debate has been relatively narrow and has not explored the likely impact of Chinese SOEs and their subsidiaries upon the shape of corporate governance in countries in which they invest. This article seeks to examine the legal contours of Chinese-controlled investment in Australia with a view to acquiring a more informed understanding of the impact of Chinese SOEs upon the Australian legal landscape.
\end{abstract}

\section{INTRODUCTION}

Chinese state-owned enterprises (SOEs) and their associated and subsidiary companies play an increasingly important role in many countries and particularly in the Australian economy; this is likely to become more important as Australia and China inevitably become more economically integrated. The 2015 Free Trade Agreement between China and Australia (CHAFTA) will help to accelerate a

* Professor of Law, School of Law, University of South Australia, and Visiting Professor of Company Law, Durham University (email: Roman.Tomasic@unisa.edu.au).

** Senior Lecturer, School of Law, University of South Australia (email: Ping.Xiong@unisa.edu.au). 
process that has been deepening in significance for some time. ${ }^{1}$ Not surprisingly, a former Australian Foreign Minister has reportedly concluded that "China is the biggest thing that Australia has going for it". ${ }^{2}$ If this is so, it is important that the nature and implications of this engagement are better understood.

Over the last decade, there has been an ongoing public policy debate in Australia over the nature of Chinese SOEs. Much of the debate has been careful to ensure that Australia remains an attractive investment destination for Chinese state-owned companies. This is in contrast to the more critical approach to SOEs that is to be found in other parts of the world, such as the United States. This argument was driven by a free trade agenda of making Australia a more attractive investment destination. Economists have also been critical of "populist" over-reaction in fears of Chinese SOEs. ${ }^{3}$

Australian businesses dealing with China have also been critical of what some have seen as the "xenophobic" and "alarmist" approach to decisions made by the Foreign Investment Review Board (FIRB) relating to Australian property acquisitions by Chinese controlled entities. ${ }^{4}$ The Business Council of Australia (BCA) has, therefore, argued that Chinese SOEs are increasingly commercially driven and that they are important in providing investment funds to Australia in the face of international competition for funds. ${ }^{5}$ The core of the liberalisation argument advanced by the BCA was that "[m]aintaining the status quo on SOE investment policy risks Australia missing out to competitor countries who are increasingly more adept at attracting these new sources of capital."6

This response paralleled the liberalisation advocated earlier by groups such as the Institute for Public Affairs (IPA) when it argued in a Senate submission that "[i]nstead of being afraid of SOEs, the Australian government should embrace the opportunities that SOEs provide in an investment

1 See Free Trade Agreement between the Government of Au stralia and the Government of the People's Republic of China [2015] ATS 15 (signed 17 June 2015, entered into force 20 December 2015).

2 Glenda Korporaal "China's still the only show in town: Carr" The Australian (Australia, 29 January 2016) at 17 and 19.

3 See Peter Drysdale "Australia short-changing itself over Chinese investment" (5 November 2012) Australian National University, Development Policy Centre <https://devpolicy.crawford.anu.edu.au>.

4 See for example the criticisms made by the executive chairperson of Bega Cheese of debates surrounding such decisions: Damon Kitney "FIRB being used as 'xenophobic weapon"' The Australian (Australia, 3 March 2016) at 21. Similar language has been attributed to former Queensland Labor Treasurer Keith De Lacey in relation to the acquisition of Tully Sugar Mill by the China Oil and Food Company: S Martin "Robert's stake in firm tied to Nimrod" The Australian (Australia, 29 February 2016) at 4. See also Annabel Hepworth "Leaders warn against a backlash on Chinese investment" The Australian (Australia, 8 August 2016) at 21; and David Uren "China snub puts asset sales at risk" The Weekend Australian (Australia, 13-14 August 2016) at 1 .

5 Business Council of Australia Discussion Paper on Foreign Investment and State-owned Enterprises: Managing the Risks to Maximise the Benefits (August 2014).

6 At 3 . 
constrained environment." ${ }^{7}$ However, in 2013, a Treasury paper pointed to the influence of Chinese SOEs upon national and local government in China and noted that "SOEs shape government policy priorities, often advancing their own interests ..." and that SOEs retain their State and Party rankings which are "reinforced by the rotation between government and SOE positions". ${ }^{8}$ More recently, a national security concern has been raised in regard to large infrastructure investments in Australia. ${ }^{9}$

This heated debate suggests the need for a more nuanced understanding of SOEs than is evident in liberalisation and narrow economic approaches. Not surprisingly, a former World Bank President and United States trade representative, Mr Richard Zoellick, has urged Australian business to adopt a more realistic approach to dealing with Chinese investment, noting that "[s]ome parts of the Australian business community have done very well from China's growth" and as a result "they don't want to do anything that will even alienate [China]". ${ }^{10}$ It is interesting to note that the United States inserted detailed provisions on foreign investment by SOEs into ch 17 of the Trans-Pacific Partnership Agreement (TPPA) proposed by the Obama administration. ${ }^{11}$

Relatively little is known about internal corporate governance practices of major Chinese government-owned companies operating in Australia. Many remain "black boxes" as their Australian subsidiaries are often set up as private companies, although 20 or so Chinese-controlled companies are Australian public companies with some obligations of transparency. In contrast to the position in China, Chinese-owned companies in Australia operate in an environment where broadly based shareholder-oriented companies are the norm. ${ }^{12}$ In contrast, in China, SOEs have followed a state-

7 Sinclair Davidson, Julie Novak and Tim Wilson "Submission to the Senate inquiry into investment by Stateowned entities" (April 2009) Parliament of Australia <www.aph.gov.au> at 17.

8 Dong Zhang and Owen Freestone "China's Unfinished State-Owned Enterprise Reforms" (2013) The Treasury <www.treasury.gov.au>.

9 David Uren "Treasurer shuts China out of grid" The Australian (Australia, 12 August 2016) at 1. There is no doubt that such concerns should be taken seriously, although they have sometimes had little impact, such as in the decision to provide a 99-year lease over the port of Darwin to a private Chinese company. See G Sheridan "Nothing to do with xenophobia" The Australian (Australia, 12 August 2016) at 1 and 4; and Paul Kelly "China Challenge is getting tougher" The Weekend Australian (Australia, 13-14 August 2016) at 1516.

10 Quoted by J Kehoe "Zoellick urges business: be realistic on China" The Australian Financial Review (Australia, 17 June 2016) at 1.

11 Trans-Pacific Partnership Agreement (signed 4 February 2016, not yet in force) <http://dfat.gov.au>.The Trump Administration has now withdrawn the United States from these discussions so it may proceed without the United States.

12 See generally Roman Tomasic and Stephen Bottomley Directing the Top 500: Corporate Governance and Accountability in Australian Companies (Allen \& Unwin, Sydney, 1993); and Meredith Jones and others "Corporate Governance, Shareholder Primacy and the Interests of Employees: Evidence From a Survey of Australian Directors" in Shelley Marshall, Richard Mitchell and Ian Ramsay (eds) Varieties of Capitalism, Corporate Governance and Employees (Melbourne University Press, Carlton, 2008) 158. 
oriented model of corporate governance, usually with a powerful and dominant state shareholder. ${ }^{13}$ The formation of private company subsidiaries and hybrid entities may serve to mask the level of state control over SOE-controlled group companies.

There is a need to identify and explain the patterns of corporate governance in groups of companies that are controlled by Chinese SOEs in Australia; this would involve examining patterns of legal compliance, including with soft law norms, such as codes of corporate governance and codes of corporate social responsibility. This should include an examination of the extent to which these patterns mirror practices found in Australian companies so as to assess the extent to which Chineseowned companies in Australia that are part of SOE-controlled groups embrace local corporate governance and legal norms, and the extent to which their practices in foreign markets continue to adhere to mainland Chinese governance norms.

Aimed at providing a comprehensive understanding of the governance methods and corporate culture in Chinese SOEs operating in Australia, this article starts to map the contours of Chinese SOE control over companies operating in Australia. It presents the issues involved in the Australian companies with investment from Chinese state-owned companies and proffers a general understanding of the issues for further research and for developing a more theoretically informed understanding of Chinese SOEs operating abroad.

\section{MAPPING AS A PRECONDITION TO ACCURATE UNDERSTANDING OF LEGAL SYSTEMS}

In obtaining a better perspective of any new terrain, it is always important to seek to prepare a reliable map. Preparing maps accurately is obviously important, but often map-making distorts reality in different ways, such as by privileging certain locations over others. In regard to understanding law, this cartographic metaphor has also seen distortions as Santos has reminded us. ${ }^{14}$ Distortion comes about from the very exercise of trying to reduce the diversity of the world to manageable proportions, by balancing representations of reality with orientation or navigation of a terrain. This suggests the existence of a plurality of legal rules and legal institutions at any one time, with most maps only reflecting the formal structures. ${ }^{15}$ Santos adds that in any one legal space, "other normative orders do operate, and are effective in the same territory". ${ }^{16}$ This means that in a legal system such as that in

13 See generally Gordon Redding and Michael A Witt The Future of Chinese Capitalism (Oxford University Press, Oxford, 2007) at 81-102.

14 Boaventura de Sousa Santos Toward a New Legal Common Sense (2nd ed, Butterworths LexisNexis, London, 2002) at 418 .

15 At $419-420$.

16 At 420 . 
Australia, the formal legislated map of law may be incomplete and that many people carry "mental maps" around with them which reflect other norms or values. ${ }^{17}$

The mapping metaphor has also been used widely by comparative lawyers when they seek to emphasise differences between legal systems or when classifying legal systems, such as into "legal families". ${ }^{18}$ However, as Siems points out, such categorisations of legal systems may be criticised for being overly simplistic, for overemphasising similarities and underemphasising differences between systems, and for ignoring the existence of hybrid legal systems. ${ }^{19}$ In addition, Siems has recognised that there may be a multiplicity of legal orders within the one state, and not just the official legal system of the state; this is sometimes referred to as legal pluralism. ${ }^{20}$ This is a theme that has also been examined at greater length by Tamanaha, who has explored how this concept has changed from medieval times, through Colonial eras and more recently in the context of globalisation. ${ }^{21}$ As Tamanaha concluded: "When placed in historical context, it is apparent that the texture of legal pluralism is intimately connected to the activities and fate of state legal systems."22 Tamanaha also cautioned against the error of believing that the "state law matters above all else" as well as the error of thinking that "legal or normative systems are parallel to state law". ${ }^{23}$

Although he was mainly discussing the implementation of foreign laws at the state level, Twining pointed to the complex patterns of diffusion of law that occur when a global perspective is taken. He warned that there is a danger of underestimating "the importance of informal processes of interaction" when transplant theorists focus merely on the spread of state law from one state to another ${ }^{24}$ In the context of the increasing globalisation of law and business activity, it is also likely that major foreign investors, such as large Chinese SOEs, will continue to be influenced by the soft law norms, values and legal cultures drawn from their country of origin. This has been common with transnational corporations operating in other parts of the world, especially in regard to corporate governance

17 Santos argues that distortions in mapping come about through the use of devices such as scale, the projection and symbolisation in maps. He then examines how each of these distorting devices affects our understanding of law: at $422-436$.

18 For a tabular illustration of changing categorisations of legal systems over time by different comparative lawyers, see Mathias Siems Comparative Law (Cambridge University Press, Cambridge, 2014) at 76.

19 At $80-93$.

20 At 107-108. This multiplicity of legal orders has long been recognised by legal scholars: see for example John Griffiths "What is Legal Pluralism?" (1986) 24 J Legal Plur 1; Sally Engle Merry "Legal Pluralism" (1988) 22 L \& Socy Rev 869; and Marc Galanter "Justice in Many Rooms: Courts, Private Ordering, and Indigenous Law" (1981) 19 J Legal Plur 1.

21 Brian Z Tamanaha "Understanding Legal Pluralism: Past to Present, Local to Global" (2008) 30 Syd LR 375.

22 At 410

23 At 410. For similar arguments, see Margaret Davies "The Ethos of Pluralism" (2005) 27 Syd LR 86.

24 William Twining "Diffusion of Law: A Global Perspective" (2004) 36 J Legal Plur 1 at 23. 
ideas. ${ }^{25}$ Twining, therefore, has urged that non-state law norms be taken seriously. ${ }^{26}$ There will be more to say about this theme below. Before exploring this theme further, the next section will examine the contours of Chinese investment as this relates to Australia.

\section{CURRENT CONTOURS OF CHINESE OUTBOUND INVESTMENT}

According to United Nations Conference on Trade and Development (UNCTAD) statistics, China has seen a steady increase of its outbound investment from 2005 to 2014, starting from USD 19.9 billion between 2005 and 2007, and reaching USD 116 billion in 2014. ${ }^{27} \mathrm{~A}$ joint report from the American Enterprise Institute and the Heritage Foundation (AEI) shows that Chinese foreign investment in Australia over the decade to 2016 comprised USD 75.5 billion, slightly less than the USD 93.31 billion invested by China in the United States over the same period. ${ }^{28}$ This investment includes both investments from SOEs and private sources. Based on AEI statistics, Australia received about 6.7 per cent of all global Chinese foreign direct investment in the decade up to $2016 .{ }^{29}$ In 2015 , it was estimated in a KPMG-Sydney University study that Chinese investment in Australia over the next decade will be over USD 90 billion. ${ }^{30}$

Among all these investments, the largest Chinese investments tend to be made in developing countries or those with substantial natural resources. ${ }^{31}$ Between 2005 and 2017, this saw South America attracting USD 144.73 billion (with USD 52.2 billion in Brazil; USD 20.6 billion in Venezuela; USD 27.5 billion in Argentina and USD 19.7 billion in Peru). Sub-Saharan Africa attracted USD 271.9 billion and the Middle East and North Africa attracted USD 149.8 billion in

25 See Janet Dine and Marios Koutsias The Nature of Corporate Governance: The Significance of National Cultural Identity (Edward Elgar, Cheltenham, 2013).

26 William Twining General Jurisprudence: Understanding Law from a Global Perspective (Cambridge University Press, Cambridge, 2009) at ch 12.

27 United Nations Conference on Trade and Development World Investment Report (2015). Peter J Buckley also draws upon data from Chinese central government agencies, the Ministry of Commerce (MOFCOM) and the State Administration of Foreign Exchange, but large state-owned enterprises (SOE) foreign direct investments are not always reported by MOFCOM statistics as these projects require State Council approval and do not need to be registered with MOFCOM: Peter J Buckley and others "Historic and Emergent Trends in Chinese Outward Direct Investment" in Peter J Buckley (ed) Foreign Direct Investment, China and the World Economy (Palgrave Macmillan, Basingstoke, 2010) 119 at 143. See also Peter Nolan Is China Buying the World? (Polity Press, Cambridge, 2012).

28 American Enterprise Institute and the Heritage Foundation "China Global investment Tracker" (2005-2017) <www.aei.org>.

29 American Enterprise Institute and the Heritage Foundation, above n 28.

30 KPMG and The University of Sydney "Demystifying Chinese Investment in Australia" (May 2015 ) at 31.

31 American Enterprise Institute and the Heritage Foundation, above n 28. 
foreign investment. There was AUD 9.46 billion in Chinese investment into Australia in 2014 and this can be compared with the USD 116 billion in foreign outbound investment from China globally in 2014. On current exchange rates, this suggests that Australia received about 5.6 per cent of Chinese foreign outbound investment; the AEI statistics put this figure at about 6.7 per cent of global Chinese outbound investments. On this basis, Australia is still a relatively small player, although if one controls for Australia's low population density, it is disproportionately higher than for countries such as the United States.

\section{A The Problem of Defining SOEs}

The OECD Guidelines on Corporate Governance of State-Owned Enterprises define SOEs broadly as follows: "any corporate entity recognised by national law as an enterprise, and in which the State exercises ownership, should be considered as an SOE". ${ }^{32}$ The UNCTAD World Investment Report defines government control as a stake of 10 per cent or more of the voting power, or where the government is the largest single shareholder. ${ }^{33}$ However, the BCA in 2014 noted that: ${ }^{34}$

While there is no consensus on the definition of an SOE, they are often defined as enterprises comprising parent enterprises and their foreign affiliates in which the government has a controlling interest (full, majority or significant minority).

The Australian FIRB uses: ${ }^{35}$

... a 15 per cent benchmark of aggregate government interest from a single foreign country to define an SOE, or 40 per cent for aggregate interest from governments from more than one foreign country.

However, more robust definitions have been developed elsewhere. For example, art 17.1 in ch 17 of the previously United States-sponsored TPPA, with which Australia and New Zealand were involved, defined SOE as meaning:

... an enterprise that is principally engaged in commercial activities in which a Party: (a) directly owns more than 50 per cent of the share capital; (b) controls, through ownership interests, the exercise of more than 50 per cent of the voting rights; or (c) holds the power to appoint a majority of members of the board of directors or any other equivalent management body.

32 Organisation for Economic Co-operation and Development OECD Guidelines on Corporate Governance of State-Owned Enterprises (OECD Publishing, Paris, 2015) [OECD] at 14.

33 United Nations Conference on Trade and Development Methodological Note: World Investment Report 2016 (United Nations, New York, 2016) at 3.

34 Business Council of Australia, above n 5, at 2.

35 At 2. 
The proposed TPPA also defined "commercial activities" by reference to an orientation to profitmaking and the production of a good or supply of a service to a consumer at a price set by the enterprise. ${ }^{36}$

\section{B Varying Attitudes to Chinese SOEs in Australia}

As we have seen, there has been an ongoing debate about SOE investment in Australia. This issue came before an Australian Senate committee in 2009. In hearings before the Senate Economics References Committee on 23 June 2009, the Institute of Public Affairs (IPA) called for liberalisation in approaches to SOE investment. The IPA has been described as a right-wing corporate funded thinktank with close ties to the Liberal Party. ${ }^{37}$ The IPA's 2009 Senate submission described itself as "the world's oldest free market think tank". ${ }^{38}$ Not surprisingly, it called for a deregulation of this area and argued strongly that Chinese SOEs should be treated as only having economic objectives, arguing: ${ }^{39}$

The central tenet of the IPA's submission is that Australia stands to attract additional foreign investment

if it eases its regulatory restrictions on such activity. This is a central policy issue ...

The IPA representative before the Senate Committee stated that "these developments are, on balance, (a) economically useful and (b) politically benign". ${ }^{40}$ In its written Senate submission, the IPA argued that: "[i]nstead of being afraid of SOEs, the Australian government should embrace the opportunities that SOEs provide in an investment-constrained environment." 41 The IPA also argued that "extra hurdles for SOEs are questionable" on the grounds that they reflect various biases. ${ }^{42}$

Others, such as Australian National University economist Peter Drysdale, have also been critical of "populist" over-reactions in fear of Chinese SOEs. ${ }^{43}$ Most business groups and economists in Australia have focused on basic economic issues without regard for more nuanced and wider social science-based analyses of SOEs and their governance by China-focused scholars.

36 See Office of the United States Trade Representative "Trans-Pacific Partnership" <https://ustr.gov> at ch 17.1.

37 See Sourcewatch "Institute of Public Affairs" <www.sourcewatch.org>.

38 Joe Hockey, Treasurer "Australia's Economic Prosperity, Address to the Institute of Public Affairs, Melbourne" (31 March 2015) The Treasury <http://jbh.ministers.treasury.gov.au>.

39 Julie Novak "Oral Submission on Behalf of the Institute of Public Affairs to the Senate Economics References Committee" (23 June 2009) at E1.

40 At E1.

41 Davidson, Novak and Wilson, above n 7, at 17.

42 At 14.

43 See Drysdale, above n 3. 
Some economists have, therefore, argued in favour of relaxing scrutiny of SOE investment, especially for local SOEs. Professor Drysdale has supported treating Chinese SOEs like nongovernment owned companies on the ground that SOE investment into Australia is beneficial. ${ }^{44}$ But, in a 2014 newspaper article, Drysdale later distinguished between large centrally controlled SOEs (whose senior executives were appointed by the Communist Party and were listed among the top officials in China), and local or provincial SOEs; this was an important distinction. Drysdale argued: ${ }^{45}$

These local SOEs collectively control more state equity than central SOEs. They are more likely to be competing against each other as well as with private firms. They are under local political pressure to be more profitable. ... There is no logical basis for treating the vast bulk of Chinese SOEs or similar investors from other states any differently from other potential investors in Australia, comply as they must with

Australian laws and corporate and other regulations.

Industry approaches have often echoed views of lobby groups and some economists. In its 2014 Discussion Paper on Foreign Investment and State-owned Enterprises: Managing the Risks to Maximise the Benefits, the BCA discussed various options for enhancing SOE investment in Australia. Like the IPA, the BCA paper was concerned that Australia may lose out to other countries in the international effort to attract Chinese SOE investment funds. The BCA asked whether the behaviour of SOEs was changing and responded by pointing to a KPMG-Sydney University report which suggested that SOEs are becoming "increasingly commercially motivated and behave like other private sector companies. Chinese SOEs are learning from past experience and adapting their approach to suit Australian market conditions." 46

The BCA discussion paper went on to assert that this was so because these SOEs are in compliance with the same domestic laws and regulations applying to other companies: SOEs employed Australian executives and appointed Australian board members; SOEs used Australian professional service firms, such as Big Four auditors "to improve their operations in Australia"; and SOEs worked to integrate themselves with local communities. ${ }^{47}$ Although all of these reasons have some merit, it is necessary to look more closely at how these factors operate in practice.

Sweeping statements alone are not convincing. The BCA acknowledged in passing that "[w]e need to accept there may be some risks associated with the operation and governance of SOE investors

44 Peter Drysdale "A New Look at Chinese FDI in Australia" (2011) 19(4) China \& World Economy 54. This journal is published by the Chinese Academy of Social Sciences.

45 Peter Drysdale "Some Chinese state-owned enterprises are more equal than others" (25 August 2014) The Australian Financial Review <www.afr.com>.

46 Business Council of Australia, above n 5, at 3.

47 At 14. 
in Australia, and acknowledge these risks are manageable." ${ }^{48}$ However, the BCA's main message was that Australia should not miss out: "Maintaining the status quo on SOE investment policy risks Australia missing out to competitor countries who are increasingly more adept at attracting these new sources of capital. 49 This approach has the hallmarks of a "race to the bottom" in standards.

A little earlier, the Australian Treasury issued an "Economic Roundup" written by Zhang and Freestone. ${ }^{50}$ This paper noted that the Chinese Government has been pushing a "broader incremental strategy in reforming the centrally planned economy" creating a hybrid economy with a growing private sector and a shrinking public sector. Although efforts were being made to make SOEs more competitive and to consolidate them through mergers and restructuring, the influence of SOEs within China upon national and local governments cannot be ignored.

As this Treasury paper noted, "SOEs shape government policy priorities, often advancing their own interests" and they retain their state and party rankings which is "reinforced by the rotation between government and SOE positions". The Treasury paper also noted that "there is much room for further corporatisation and corporate governance reforms". But SOE reform cannot proceed independently as SOEs are so interconnected. As a result, reforms will always be judged by their effect on social and economic stability in China.

\section{Some Judicial Approaches to Chinese SOEs in Australia}

From time to time, Australian courts have come to reflect upon the nature of Chinese SOEs and how they may be subject to Australian legal remedies. In Forrest $v$ Australian Securities and Investments Commission, the High Court of Australia reminded us that SOEs were different from other companies. ${ }^{51}$ In this case, the corporate regulator, the Australian Securities and Investments Commission (ASIC), had for some time been pursuing the Fortescue Mining Group's (FMG) Chairman and Chief Executive, Andrew Forrest, seeking to have him disqualified as a director. This action was being taken on the grounds that Forrest had allegedly misled the market by his announcement to the stock market that FMG had signed contracts with three massive Chinese SOEs to build a mine as well as an associated port and railway for FMG in Western Australia.

ASIC argued that the skimpy paper work presented by Forrest did not represent a fully formed contract as, for example, it did not contain appropriate enforcement provisions for FMG to use in the event of a contractual breach by the SOEs. The Full Federal Court agreed that there had been a breach of disclosure rules and found in favour of ASIC, but the High Court reversed this finding, concluding that relevant persons in the market had not been misled. Whilst, in passing, noting that these contracts

48 At 15.

49 At 3 .

50 Zhang and Freestone, above $\mathrm{n} 8$.

51 Forrest v Australian Securities and Investments Commission [2012] HCA 39, (2012) 247 CLR 486. 
(headed "framework agreements") may well have been made under Chinese law, what is interesting in the High Court of Australia's judgment (a decision of French CJ, Gummow, Hayne, Heydon and Kiefel JJ) are the insights into how large Chinese SOEs should be seen in the context of Australian law. As the High Court observed: ${ }^{52}$

ASIC contends that Fortescue's target audience was being misled in being persuaded that the agreement put Fortescue into a position in which it was practicable for it to force CREC to design, build, transfer and finance the railway. But an audience which read Fortescue's statements that way might be expected to ask: how is a State-owned enterprise of the People's Republic of China to be forced to do anything?

The High Court also criticised the Federal Court on the grounds that: ${ }^{53}$

No consideration was given, at any point of the Full Court's analysis, to the significance, if any, of the fact that the counter-party to Fortescue in each agreement was a foreign state-owned entity. ... Yet no consideration was given, at any point of the Full Court's analysis, to what law governed the agreements.

It is not the intention here to fully consider how Chinese SOEs have been dealt with by Australian courts; that is something for another day. However, the High Court's statements in Fortescue suggest that they may well lead to a review of an overly rigid approach to some basic legal rules, such as the doctrine of disclosure which was the subject in this case. ${ }^{54}$

In the meantime, the Australian and Chinese legal systems may be converging to some degree as both economies become more integrated, although these are long term processes. Australia has in many ways clearly moved much closer to China in recent years; economically, Australia is certainly very dependent upon China as is illustrated by the fact that the Australian dollar is often seen in the financial press as a proxy for the Chinese Yuan. ${ }^{55}$ The challenge here is to assess the degree to which there has also been a sharing of legal ideas and corporate governance values in response to this greater economic integration.

\section{The China-Australia Free Trade Agreement}

Despite concerns of the kind raised in the Australian Treasury's SOE paper, the BCA's position in regard to Chinese SOEs seems to have been well received by the Australian Government, if the passage of the CHAFTA in 2015 is indicative. In guidance issued by the Department of Foreign Affairs and Trade (DFAT) in 2015, it was noted that the new CHAFTA will promote Chinese

52 At [105].

53 At [46].

54 This issue of legal principle has not been without some controversy in Australia. See John Humphrey and Stephen Corones "Forrest v ASIC: A 'Perfect Storm"' (2014) 88 ALJ 26.

55 See for example Jessica Sier "China proxy Aussie dollar hits four-month low" The Sydney Morning Herald (online ed, Sydney, 14 January 2016). 
investment in Australia by generally liberalising the screening threshold for private Chinese investments in non-sensitive sectors considered by the FIRB. Under the CHAFTA, the threshold for the review of foreign acquisitions has now been generally raised from AUD 252 million to AUD 1,094 million, but there will be continuous screening of the investments at lower thresholds in regard to agribusinesses and sensitive sectors. ${ }^{56}$ In regard to SOEs, DFAT's guidance added: ${ }^{.7}$

FIRB also continues to screen all direct investments, new business proposals and acquisitions of interests in land (including agricultural land), by Chinese state-owned enterprises, regardless of transaction size. ChAFTA does not change these arrangements in any way, consistent with the Government's practice in other FTAs.

Australia has indicated that it will review the position of Chinese Government investors (whether these are SOEs or Sovereign Wealth Funds) during the initial three year revision period of the CHAFTA. In regard to labour matters, where the investment has an expected capital expenditure of AUD 150 million, Chinese companies and SOEs will be able to employ Chinese workers under the Investment Facilitation Agreement (IFA) which has streamlined and relaxed Australian immigration laws. IFAs are managed within the framework of Australia's 457 visa system. ${ }^{58}$

\section{CHINESE STATE-OWNED ENTERPRISES IN AUSTRALIA}

\section{A The Landscape of Chinese SOEs in Australia}

A substantial number of Chinese SOEs and their subsidiaries are already present in Australia. Tables 1 and 2 list 66 major Chinese SOEs with a presence in Australia with 39 centrally controlled SOEs (in Table 1) and 27 provincially controlled SOEs (in Table 2). Among these SOEs, most have a number of Australian subsidiaries: the conglomerate CITIC has a larger number (49) with the next highest number of subsidiaries being 11 for COSCO (China Shipping Group).

In 2016, China's 39 centrally controlled SOEs in Australia had a total of 130 Australian subsidiaries, and China's 27 provincially controlled SOEs in Australia had a total of 84 Australian subsidiaries. Among the provincially controlled SOEs, Shanghai Sugar, Cigarette and Wine Co had the largest number at 12 subsidiaries and it was followed by Yanzhou Coal Mining Co with 11 subsidiaries in Australia. As one would expect, the number of subsidiaries seems to be growing with each new investment project.

Tables 1 and 2 set out the names of Chinese SOEs currently operating in Australia, indicating their industry sector and the number of their Australian subsidiaries. These tables also provide an

56 Department of Foreign Affairs and Trade, Australia "Factsheet: Investment and Investor-State Dispute Settlement (ISDS)" (2015) <http://dfat.gov.au> [DFAT].

57 DFAT, above n 56

58 See Department of Immigration and Border Protection, Australia "Temporary Work (Skilled) visa (subclass 457)" <www.border.gov.au>. 
indication of the relative size of these entities by reference to their standing in the Fortune Global 500 listing of global companies: 33 of the 39 centrally controlled Chinese SOEs appear on the Fortune Global 500 listing. In contrast, only five of the 27 provincially controlled SOEs listed in Table 2 are included in the Fortune Global 500 listing.

Despite assumptions to the contrary, it is important to note that the Chinese state and its SOEs are not monolithic or homogenous. However, international engagement within host countries has produced what Guo and others refer to as the "international socialization of SOEs".59 This expression has been used in the international literature to refer to "the process that is directed toward a state's internalization of the constitutive beliefs and practices institutionalized in its international environment". ${ }^{60}$ Guo and others also argue that "Chinese firms and the Chinese state will tend to comply with local practices when and where there is sufficient pressure to do so". ${ }^{61}$ However, they add that Chinese SOEs have displayed "a reluctance or failure to quickly adapt to local practices". ${ }^{6}$

Table 1: Chinese Centrally Controlled SOEs by level of control and number of subsidiaries operating in Australia in 2016

\begin{tabular}{|c|c|c|c|c|}
\hline No & Chinese Parent Company Name & $\begin{array}{c}\text { No of } \\
\text { Australian } \\
\text { Subsidiaries }\end{array}$ & $\begin{array}{c}\text { Fortune 500 } \\
\text { Global } \\
(2015)\end{array}$ & Industry Sectors \\
\hline 1 & Agricultural Bank of China Ltd & 1 & 36 & Banking \\
\hline 2 & Aluminium Corporation of China & 2 & 240 & Mining \\
\hline 3 & Anshan Iron and Steel Group & 1 & 451 & Mining \\
\hline 4 & $\begin{array}{l}\text { Aviation Industry Corporation of China } \\
\text { (AVIC) }\end{array}$ & 3 & 159 & Renewables \\
\hline 5 & Bank of China Ltd & 1 & 45 & Banking \\
\hline 6 & $\begin{array}{l}\text { Baosteel (Shanghai Baosteel Group } \\
\text { Corporation) }\end{array}$ & 4 & 218 & Mining \\
\hline 7 & $\begin{array}{l}\text { CCCC (China Communications } \\
\text { Construction Corporation) }\end{array}$ & 1 & 165 & Engineering \\
\hline 8 & ChemChina & 6 & 265 & Rubber, plastics \\
\hline 9 & $\begin{array}{l}\text { China Coal Geology Engineering } \\
\text { Corporation (CCGEC) }\end{array}$ & 2 & - & Mining \\
\hline 10 & China Construction Bank Corporation & 1 & 29 & Banking \\
\hline
\end{tabular}

59 Yingjie Guo and others "Chinese outward direct investment: case studies of SOEs going global" in John Garrick (ed) Law and Policy for China's Market Socialism (Routledge, New York, 2012) 131.

60 At 132 .

61 At 132 .

62 At 135. 


\begin{tabular}{|c|c|c|c|c|}
\hline No & Chinese Parent Company Name & $\begin{array}{c}\text { No of } \\
\text { Australian } \\
\text { Subsidiaries }\end{array}$ & $\begin{array}{c}\text { Fortune } 500 \\
\text { Global } \\
(2015)\end{array}$ & Industry Sectors \\
\hline 11 & China Electronics Corporation & 2 & 366 & $\begin{array}{l}\text { Renewables, electronics, } \\
\text { manufacturing }\end{array}$ \\
\hline 12 & China Huaneng Group & & 224 & Investment \\
\hline 13 & China Merchants Group & 9 & 235 & Logistics, mining, foodstuff \\
\hline 14 & $\begin{array}{l}\text { China Metallurgical Corporation of } \\
\text { China Ltd }\end{array}$ & & 326 & Mining \\
\hline 15 & China Minmetals Corporation & 3 & 198 & Mining \\
\hline 16 & China National Building Material Group & 1 & 270 & Retail \\
\hline 17 & $\begin{array}{l}\text { China National Cereals, Oils and } \\
\text { Foodstuffs Corporation (COFCO) }\end{array}$ & 6 & 272 & Foodstuffs \\
\hline 18 & $\begin{array}{l}\text { China National } \\
\text { Corporation (Group) }\end{array}$ & 1 & 72 & Oil and gas \\
\hline 19 & $\begin{array}{l}\text { China National Petroleum Corporation } \\
\text { (CNPC) }\end{array}$ & 4 & 4 & Oil and gas \\
\hline 20 & China Poly Group & 1 & 457 & Real estate \\
\hline 21 & China Power Investment Corporation & & 403 & Mining \\
\hline 22 & China Publishing Group & 1 & & Publishing \\
\hline 23 & $\begin{array}{l}\text { China Railway Engineering } \\
\text { Construction Group (CREC) }\end{array}$ & 2 & 71 & Engineering \\
\hline 24 & $\begin{array}{l}\text { China Railway Materials Commercial } \\
\text { Corporate (CRMCC) }\end{array}$ & 1 & - & Logistics \\
\hline 25 & China Shenhua Energy Company & 4 & 196 & Mining \\
\hline 26 & China Shipping Group (COSCO) & 8 & 432 & $\begin{array}{l}\text { Logistics, food imports, real } \\
\text { estate }\end{array}$ \\
\hline 27 & China Southern Airlines & 1 & - & Cargo, airline \\
\hline 28 & China State Construction Engineering & & 37 & Construction \\
\hline 29 & China Telecom & 2 & 160 & Telecom \\
\hline 30 & China Unicom & 1 & 227 & Telecom \\
\hline 31 & $\begin{array}{l}\text { ChinaCoal (China National Coal Group } \\
\text { Corporation) }\end{array}$ & 2 & - & Mining \\
\hline 32 & CITIC Group & 42 & 186 & Mining \\
\hline 33 & $\begin{array}{l}\text { Industrial and Commercial Bank of } \\
\text { China Ltd }\end{array}$ & 1 & 18 & Banking \\
\hline 34 & SinoChem Corporation & 1 & 105 & Chemicals \\
\hline 35 & Sinomach & 1 & 288 & Machinery \\
\hline
\end{tabular}




\begin{tabular}{c|lccc} 
No & \multicolumn{1}{|c}{ Chinese Parent Company Name } & $\begin{array}{c}\text { No of } \\
\text { Australian } \\
\text { Subsidiaries }\end{array}$ & $\begin{array}{c}\text { Fortune 500 } \\
\text { Global } \\
(\mathbf{2 0 1 5})\end{array}$ & Industry Sectors \\
\hline $\mathbf{3 6}$ & $\begin{array}{l}\text { Sinopec (China National Petrochemical } \\
\text { Corporation) }\end{array}$ & 5 & 2 & Oil and gas \\
$\mathbf{3 7}$ & Sinosteel & 4 & - & Mining \\
$\mathbf{3 8}$ & State Grid & 4 & 7 & Energy \\
$\mathbf{3 9}$ & China XD Group & 1 & - & Electrical
\end{tabular}

Table 2: Chinese Provincially Controlled SOEs in Australia in 2016

\begin{tabular}{|c|c|c|c|c|}
\hline No & Chinese Parent Company Name & $\begin{array}{c}\text { No of } \\
\text { Australian } \\
\text { Subsidiaries }\end{array}$ & $\begin{array}{c}\text { Fortune } \\
\text { 500 Global } \\
\text { (2015) }\end{array}$ & Industry Sectors \\
\hline 1 & Chaoyang Longshan Asset Management & 3 & - & Retail \\
\hline 2 & China Molybdenum Group & 3 & - & Mining \\
\hline 3 & $\begin{array}{l}\text { Chonggqing Iron and Steel (Group) Co } \\
\text { Ltd (CISC) }\end{array}$ & 1 & - & Mining \\
\hline 4 & $\begin{array}{l}\text { Fujian Provincial Communication } \\
\text { Transportation Group Co Ltd }\end{array}$ & & - & Investment \\
\hline 5 & $\begin{array}{l}\text { Guangdong Rising Asset Management } \\
\text { (GRAM) }\end{array}$ & 3 & - & Mining \\
\hline 6 & Haier Group & 4 & - & White goods \\
\hline 7 & Hainan Airlines Group (HNA) & 8 & 464 & Aviation \\
\hline 8 & Hebei Iron and Steel Co Ltd & 3 & 239 & Mining \\
\hline 9 & Hisense Co Ltd & 2 & - & White goods \\
\hline 10 & Jinchuan Group & 2 & - & Mining \\
\hline 11 & Jinjiang International (Group) Co Ltd & 1 & - & Hotels \\
\hline 12 & Maanshan Iron \& Steel Co Ltd & 1 & - & Mining \\
\hline 13 & Shandong Energy Group Co & 4 & 373 & Mining \\
\hline 14 & Shandong Gold & 2 & - & Mining \\
\hline 15 & Shandong Iron and Steel Co Ltd & & - & Mining, iron \\
\hline 16 & Shanghai Construction Group & 1 & - & Construction \\
\hline 17 & Shanghai Electric Group & 2 & - & Mining, coal \\
\hline 18 & $\begin{array}{l}\text { Shanghai Sugar, Cigarette and Wine } \\
\text { Group (SSCW Group) }\end{array}$ & 12 & - & Foodstuffs \\
\hline 19 & $\begin{array}{l}\text { Shenzhen Zhongjin Lingnan Nonfemet } \\
\text { Co Ltd }\end{array}$ & 5 & - & Mining \\
\hline 20 & Shoungang Group & 1 & 402 & Mining \\
\hline 21 & Sichuan Airlines & 1 & - & Airline \\
\hline
\end{tabular}




\begin{tabular}{c|lccc}
$\mathbf{N o}$ & \multicolumn{1}{|c}{ Chinese Parent Company Name } & $\begin{array}{c}\text { No of } \\
\text { Australian } \\
\text { Subsidiaries }\end{array}$ & $\begin{array}{c}\text { Fortune } \\
\mathbf{5 0 0} \text { Global } \\
\mathbf{( 2 0 1 5 )}\end{array}$ & Industry Sectors \\
\hline $\mathbf{2 2}$ & Tongrentang & 5 & - & Pharmaceuticals \\
$\mathbf{2 3}$ & Tsinghua Holdings Company & 1 & 500 & $\begin{array}{c}\text { Consumer goods, } \\
\text { manufacturing }\end{array}$ \\
$\mathbf{2 4}$ & Wugang Iron and Steel & 3 & - & Iron \\
$\mathbf{2 5}$ & Yanzhou Coal Mining Co & 11 & - & Mining \\
$\mathbf{2 6}$ & Yunnan Tin Group & 4 & - & Mining \\
$\mathbf{2 7}$ & Zijin Mining Group Co Ltd & 1 & - & Mining
\end{tabular}

Comparing the size of Chinese SOEs in Australia, it is interesting to note that eight "Australian" registered companies are included in the Fortune Global 500 list of companies, comprising four major banks, two large food companies, a mining company and a telecommunications company. This is perhaps a comparatively high number of companies if we control for Australia's relatively small population compared with China. Table 3 illustrates the current list of Australian registered companies on this Fortune 500 listing.

Table 3: Australian companies on the Fortune Global 500 list in 2015

\begin{tabular}{c|lcc}
\multicolumn{1}{c}{ No } & \multicolumn{1}{|c}{$\begin{array}{c}\text { Name of Australian Registered } \\
\text { Company }\end{array}$} & $\begin{array}{c}\text { Fortune } \\
\mathbf{5 0 0} \text { Global }\end{array}$ & Industry Sectors \\
\hline $\mathbf{1}$ & BHP Billiton Ltd & 139 & Mining \\
$\mathbf{2}$ & Westfarmers Ltd & 171 & Foodstuffs \\
$\mathbf{3}$ & Woolworths Ltd & 181 & Foodstuffs \\
$\mathbf{4}$ & National Australia Bank Ltd & 266 & Banking \\
$\mathbf{5}$ & Commonwealth Bank Ltd & 269 & Banking \\
$\mathbf{6}$ & Westpac Banking Corporation Ltd & 330 & Banking \\
$\mathbf{7}$ & ANZ Banking Group Ltd & 368 & Banking \\
$\mathbf{8}$ & Telstra Corporation Ltd & 481 & Telecom
\end{tabular}

\section{$B$ The Culturally Embedded Nature of Corporate Laws}

This article does not seek to exhaustively examine the policies driving China's foreign investments, as others have already traversed this ground. ${ }^{63}$ These policies have changed dramatically over the last 25 years since the somewhat narrowly oriented 1991 Opinion of the State Planning Commission on Strengthening the Administration of Overseas Investment Projects, which was

63 See generally Peter J Buckley and others "The determinants of Chinese outward foreign direct investment" (2007) 38 Journal of International Business Studies 499. 
endorsed by China's State Council. ${ }^{64}$ In 2004, a "new era" began with the State Council's Decision on the Reform of the Investment System. ${ }^{65}$

Despite the "end of history" rhetoric which has seen claims made that the world is experiencing an increasing convergence in corporate law, this convergence has often been somewhat superficial. ${ }^{66}$ It is always necessary to examine the law in action to test the level of convergence; the degree of embeddedness of a new law or legal norm has been seen as an increasingly important issue in any discussion of corporate governance. ${ }^{67}$ In his classic work on corporate governance patterns, Mark Roe has shown that the structure of corporate law in different countries is a product of local political forces, producing a literature on the political determinants of corporate governance and the persistence of "path dependency". ${ }^{68}$ Many writers have also drawn attention to the political determinants of China's corporate governance, a country where the state plays a powerful role in many sectors. ${ }^{69}$

The distinctive nature of Chinese corporate governance practices has been widely discussed in the scholarly literature; some have even described it as being "unique".${ }^{70}$ Dr Alice de Jonge's longitudinal study of the first mainland Chinese companies to list on the stock exchange in Hong Kong illustrated the inflexible nature of governance arrangements in these companies. ${ }^{71}$

Similar rigidities may well occur with Chinese companies in Australia. Corporate lawyers, such as Dine and Koutsias have pointed to the significance of national cultural identity in corporate

64 State Development Planning Commission, China Opinion of the State Planning Commission on Strengthening the Administration of Overseas Investment Projects (5 March 1991).

65 National Development and Reform Commission, China Decision of the State Council on Reform of the Investment System (Guofa Paper No 20, 2004). See Jianfu Chen "China's outward direct investment in context: from 'open door' to 'going out"' in John Garrick (ed) Law and Policy for China's Market Socialism (Routledge, New York, 2012) 21 at 21 and 29.

66 Douglas M Branson "The Very Uncertain Prospect of 'Global' Convergence in Corporate Governance" (2001) 34 Cornell Intl LJ 321

67 It is always necessary to consider how well governance practices and norms have been embedded in an organisation. See Cynthia A Williams and Peer Zumbansen (eds) The Embedded Firm: Corporate Governance, Labor, and Finance Capitalism (Cambridge University Press, Cambridge, 2011).

68 Mark J Roe Political Determinants of Corporate Governance: Political Context, Corporate Impact (Oxford University Press, New York, 2003).

69 See for example Chenxia Shi The Political Determinants of Corporate Governance in China (Routledge, Abingdon (Oxon), 2012).

70 See Yan Liu, Guclu Atinc and Mark Kroll "The Unique Nature of Chinese Corporate Governance Practices" (2011) 28 Journal of Business Strategies 29.

71 Alice de Jonge Corporate Governance and China's H-Share Market (Edward Elgar Publishing, Cheltenham, 2008). 
governance practices. ${ }^{72}$ Dine and Koutsias concluded that the most important conclusion of their research was that national corporate governance "reflects public policy choices". ${ }^{73}$ Each country has passed a set of laws that shape the structure of its firms in a way that reflects the dominant ideological and political principles prevailing in its society. They noted that as a result, even in the European Union, "harmonisation of national corporate governance models has been minimal". ${ }^{74}$ Dine and Koutsias warn that "[t]he inability to agree on a commonly accepted definition of corporate governance betrays among others the fundamental questions that emerge when debating corporate governance." 75

\section{SOEs and their Subsidiaries under Australian Corporate Laws}

We argue that these factors have implications for the way in which Chinese-controlled companies will operate abroad in countries such as Australia. Foreign companies (such as an SOE) undertaking business in Australia are required to be registered under Part 5B.2 of the Corporations Act 2001 (Cth). ${ }^{76}$ The Foreign Acquisitions and Takeovers Act 1975 (Cth) sets out the legislative framework for foreign acquisitions in Australia. The Treasurer relies upon advice from the FIRB in this regard.

This allows the Treasurer to block proposals that are contrary to the perceived "national interest" or to impose conditions on any such foreign acquisition in Australia. ${ }^{77}$ This Foreign Investment Policy was updated in 2015 to include new policies in regard to the acquisition of urban real estate by foreign entities. ${ }^{78}$ In 2016, the Policy was further updated and tightened by the Turnbull Government. ${ }^{79}$ In applying the national interest test, special attention is given to government-owned entities. Under the Foreign Investment Policy. ${ }^{80}$ The Foreign Investment Policy notes that a proposal by an SOE may yet be seen to be in the national interest when regard is had to the existence of external partners or shareholders in the investment; the level of non-associated ownership interests; the governance arrangements for the investment and ongoing arrangements to protect Australian interests from non-

72 Dine and Koutsias, above n 25.

73 At 313

74 At 313

75 At 315 .

76 See Australian Securities and Investments Commission "Foreign Companies" <http://asic.gov.au>.

77 See Treasurer "Foreign Investment Policy" (January 2011) <http://australia.org>. Also see for example the conditions imposed by the Treasurer upon Minmetals in its acquisition of OZ Minerals and the conditions imposed on Yancoal's takeover of Felix Resources.

78 See generally Parliament of Australia "Australia's foreign investment policy" <www.aph.gov.au>.

79 Scott Morrison "Media Releases" (18 March 2016) <http://sjm.ministers.treasury.gov.au>.

80 Treasurer Australia's Foreign Investment Policy (1 July 2017) Australian Government Foreign Investment Review Board <http://firb.gov.au> especially at 6. 
commercial dealings; and whether the target will be listed on the Australian Securities Exchange or another recognised exchange. ${ }^{81}$

However, in responding to a bid by State Grid, a major Chinese electricity infrastructure company, to acquire a majority stake in the New South Wales Government's electricity distribution infrastructure, it seems when approving such foreign investments, the Federal Treasurer will apply a series of informal rules which become more stringent when dealing with investment by SOEs. These informal preferences seem to require that half of the board members of the local company be resident in Australia; the company has an independent chair and is run as an independent entity; key data is not removed from the country; and SOEs have a 50 per cent ownership limit placed on their local investment. ${ }^{82}$ This reflects an emerging recognition of the importance of corporate governance considerations in regard to companies controlled by a foreign SOE.

SOE subsidiaries that have been incorporated in Australia are formally subject to the provisions of the Corporations Act 2001 (Cth), but as most of these Chinese-controlled companies are private companies, little public information will be known about their internal arrangements and relatively weak public regulation results. Public company subsidiaries of an SOE will have a greater exposure to local legal rules, such as Australian information disclosure requirements. Listed SOE subsidiary companies will also be subject to local corporate governance standards, such as the Corporate Governance Principles issued by the ASX Corporate Governance Council. ${ }^{83}$ However, it is important to remember the warning of Christopher Stone about the limits of corporate law rules in large corporate groups. ${ }^{84}$ Common law rules, such as fiduciary duties, should also apply to SOE subsidiaries incorporated in Australia. To obtain a more nuanced understanding of factors affecting the management of Chinese-controlled companies, it may be helpful to look more closely at country of origin effects, or the impact of Chinese law and culture on governance practices.

\section{CHINESE LAW AND CULTURE REGARDING CORPORATE GOVERNANCE}

\section{A "Hard Law" Norms}

Understanding and dealing with China's SOEs presents a major practical challenge. All too often, Australian debates, referred to above, have merely seen these entities in simple economic or narrow

81 See Vivienne Bath "Foreign Investment, the National Interest and National Security - Foreign Direct Investment in Australia and China" (2012) 34 Syd LR 5.

82 See David Uren "Informal 'treasurer's preferences' govern Transgrid bidding" The Australian (Sydney, 9 August 2015) at 1 and 2.

83 Australian Stock Exchange, ASX Corporate Governance Council Corporate Governance Principles and Recommendations (3rd ed, Sydney, 2014).

84 See Christopher D Stone Where the Law Ends: The Social Control of Corporate Behavior (Harper \& Row, New York, 1975). 
legalistic terms or have allowed them to be simplistically framed in popular discussions as threatening. ${ }^{85}$ There is a need for a more nuanced and sociologically informed understanding of Chinese SOEs operating in Australia. Although "hard law" norms have now progressively been inserted into Chinese company law statutes, the implementation of these norms can still be greatly influenced by political and cultural factors in China.

Chinese corporate governance norms have developed slowly in China in recent decades. Movement towards the empowerment of minority shareholders and independent directors has been relatively limited. ${ }^{86}$ Little opportunity is given to independent directors or managers in Chinese companies to challenge how an enterprise is controlled; this reflects the dominant position of the chairperson and managing director in most Chinese SOEs. As Redding and Witt (and others) have noted, this often leaves corporate control in Chinese SOEs in the hands of insiders. ${ }^{87}$ In many ways, it also reflects the importance that is given to the Communist Party retaining its dominant position of power and in ensuring that social stability is preserved in China. ${ }^{88}$

The weak enforcement of company law statutes in China has created a gap that soft laws or "civil regulation" may be used to fill. This is especially so in the context of increasing globalisation of corporate activity. ${ }^{89}$ Historically, China's SOEs have grown out of the planned economy and the use of five year plans in setting national economic goals. ${ }^{90}$ Although the planned economy model has now largely been left behind, its history has inevitably left an imprint upon the culture of Chinese

85 See generally Colin Hawes "'Framing' Chinese hi-tech firms: A political and legal critique" (2015) 30 Aust Jnl of Corp Law 34.

86 Neil Andrews and Roman Tomasic "Directing China's Top 100 Listed Companies: Corporate Governance in an Emerging Market Economy" (2006) 3 Corporate Governance Law Review 245; and Roman Tomasic and Neil Andrews "Minority Shareholder Protection in China's Top 100 Listed Companies" (2007) 9 Austl J Asia L 88 .

87 Redding and Witt, above n 13, at 99.

88 Dong Zhang "Losing Money or Losing Power: The Political Economy of the Reform of China's State-Owned Enterprises (SOEs)" in Yiping Huang and Ron Duncan (eds) State Owned Enterprises in China: Autonomy, Incentive and Competition (Asia Pacific Press, Canberra, 1998) 76. See generally Rowan Callick The Party Forever: Inside China's Modern Communist Elite (Palgrave Macmillan, New York, 2013); Richard McGregor The Party: The Secret World of China's Communist Rulers (HarperCollins, New York, 2011); and David Shambaugh China's Communist Party: Atrophy and Adaptation (University of California Press, Berkeley, 2008).

89 David Vogel "Taming Globalization? Civil Regulation and Corporate Capitalism" in David Coen, Wyn Grant and Graham Wilson (eds) The Oxford Handbook of Business and Government (Oxford University Press, Oxford, 2010) 472 .

90 See generally Barry Naughton Growing out of the Plan: Chinese Economic Reform 1978-1993 (Cambridge University Press, Cambridge, 2008); and John Garrick (ed) Law and Policy for China's Market Socialism (Routledge, New York, 2012). 
SOEs. ${ }^{91}$ From the late 1970 s, efforts have begun to be made to introduce a more market-based system into China under the leadership of premier leader Deng Xiaoping. ${ }^{92}$ SOEs were no longer directly attached to ministries and became increasingly independent.

China's SOEs can be divided into three broad categories or groups. The first includes industrial and commercial enterprises based at both the provincial and national level. In 2011, there were 144,700 such enterprises, with only a little more than 100 of these under the direct national supervision of the State-owned Assets Supervision and Administration Commission (SASAC). The second group includes banking and financial companies; whilst the third group includes media, publications, culture and entertainment companies. ${ }^{93}$ In 2015, SASAC had 112 large SOEs under its direct control, although the number of SOEs under the control of SASAC may progressively be reduced through consolidations and mergers. ${ }^{94}$

The process of economic law reform in China during the 1990s included the passage of China's first Company Law in 1993. This Company Law was primarily focused upon the corporatisation of state-owned enterprises and did not lead to the development of more robust Western-style corporate governance principles. ${ }^{95}$ These reforms culminated with China gaining entry to membership of the World Trade Organization in December 2001. In 2003, China established SASAC, with the responsibility of holding and overseeing state shares in major SOEs. SASAC has pushed for corporate governance reforms and the diversification of SOE ownership structures. ${ }^{96}$ This company legislation was further amended, culminating in the enactment of the new Company Law in 2005 and in $2013 .{ }^{97}$ The 2005 law began to enhance corporate governance principles, rights and institutions, although

91 See generally Jonathan Story "China and the Multinational Experience" in David Coen, Wyn Grant and Graham Wilson (eds) The Oxford Handbook of Business and Government (Oxford University Press, Oxford, 2010) 346 at 350-353.

92 John Hassard and others China's State Enterprise Reform: From Marx to the market (Routledge, New York, 2007).

93 Zhang and Freestone, above n 8.

94 Alice de Jonge "China's grip still tight on state-owned enterprises" (17 September 2015) The Conversation <http://theconversation.com>.

95 Fang Liufang "China's Corporatization Experiment" (1995) 5 Duke J Comp \& Intl L 149; and Nicholas C Howson "China's Company Law: One Step Forward, Two Steps Back? A Modest Complaint" (1997) 11 Columbia Journal of Asian Law 127.

96 Zhang and Freestone, above $\mathrm{n} 8$.

97 See generally J Wang Company Law in China: Regulation of Business Organizations in a Socialist Market Economy (Edward Elgar Publishing, Cheltenham, 2014). 
large Chinese SOEs have continued to be treated differently. However, the implementation of these new company law rules and principles has been affected by political and cultural forces. ${ }^{98}$

As a result, it has been argued that in a state-controlled system such as China's, corporate governance in Chinese SOEs should reflect domestic settings, rather than merely adopting Western models. ${ }^{99}$ Miles and Zhang add that the presence of the state as majority shareholder in China's SOEs "has negative consequences for corporate governance in Chinese companies" 100 and that "[c]orporations which are dominated by insiders are limited both in their corporate governance systems and learning capacity." 101 The dominance of the state leaves little room for effective intervention of non-state institutions in corporate governance in Chinese companies. ${ }^{102}$ This may have entrenched the idea of majority control in the corporate governance mindsets of controllers of major Chinese companies.

\section{$B$ "Soft Law" Influence in Chinese SOEs' Corporate Governance}

In contrast to the hard law norms of the kind found in company law statutes, "soft law" norms are becoming increasingly important in large internationally active companies which have moved beyond the limits of the nation state. ${ }^{103}$ These norms have included corporate social responsibility (CSR) rules, ${ }^{104}$ but they are much broader than this, reflecting the rise in the use of soft law standards in the context of globalisation. ${ }^{105}$ In 2015, the OECD revised its Guidelines on Corporate Governance of

98 See generally Roman Tomasic "Company Law Implementation in the PRC: The Rule of Law in the Shadow of the State" (2015) 15 JCLS 285; Qingxiu Bu "Will Chinese Legal Culture Constrain Its Corporate Governance-Related Laws" (2015) 15 JCLS 103; and Kenneth Lieberthal and Geoffrey Lieberthal "The Great Transition" (2003) 81(10) Harvard Business Review 70.

99 See for example Lilian Miles and Zhong Zhang "Improving Corporate Governance in State-owned Corporations in China: Which Way Forward?" (2006) 6 JCLS 213 at 222.

100 At 232 .

101 At 245 .

102 Donald C Clarke "The role of non-legal institutions in Chinese corporate governance" in Hideki Kanda, KonSik Kim and Curtis J Milhaupt (eds) Transforming Corporate Governance in East Asia (Routledge, New York, 2008) 168.

103 See J Braithwaite Regulatory Capitalism: How it works, ideas for making the world better (Edward Elgar Publishing, Cheltenham, 2008) at 8-12; Chris Brummer Soft Law and the Global Financial System: RuleMaking in the 21st Century (Cambridge University Press, Cambridge, 2012); and Steven K Vogel Freer markets more rules: Regulatory Reform in Advanced Industrial Countries (Cornell University Press, Ithaca (NY), 1996).

104 Bryan Horrigan Corporate Social Responsibility in the 21st Century (Edward Elgar Publishing, Cheltenham, 2010).

105 See Brummer, above n 103; and AK Bjorklund and A Reinisch (eds) International Investment Law and Soft Law (Edward Elgar Publishing, Cheltenham, 2012). 
State-Owned Enterprises. ${ }^{106}$ The OECD states that SOE corporate governance faces two conflicting challenges. First, SOEs "may suffer from undue hands-on and politically motivated ownership interference, leading to unclear lines of responsibility, a lack of accountability and efficiency losses in the corporate operations". 107

Secondly, SOEs are also seen to suffer from: ${ }^{108}$

... a lack of any oversight due to totally passive or distant ownership by the state [that] can weaken the incentives of SOEs and their staff to perform in the best interest of the enterprise and the general public who constitute its ultimate shareholders, and raise the likelihood of self-serving behaviour by corporate insiders.

Due to the "complex web of accountabilities" faced by SOEs, the OECD warned:109

$\ldots$ at the level of the state, the enforcement of commercial laws and regulations against SOEs can create unique challenges because of intra-governmental friction resulting from regulators bringing enforcement actions against entities controlled by the government.

In this context, the social fabric of SOEs becomes increasingly important and soft law norms have often been seen as useful in facilitating their internationalisation. ${ }^{110}$ There has also been an emerging body of Chinese and international soft law norms regarding the governance of Chinese companies operating in Australia. In some ways, this has been facilitated by art 5 of the 2005 Company Law which requires Chinese companies to, inter alia, "assume social responsibility". ${ }^{111}$ Chinese SOEs are increasingly being subject to corporate social responsibility codes that have been formulated in China, and these codes often reflect strong Chinese national characteristics. These soft law norms may be compared to Western codes of conduct and statements of corporate governance, but they arise from a very different social context and are often politically determined.

106 OECD, above n 32 .

107 At 12 .

108 At 12.

109 At 12

110 See generally Larry Catá Backer "A Lex Mercatoria for Corporate Social Responsibility Codes Without the State? A Critique of Legalization within the State under the Premises of Globalization" (2017) 24 Ind J Global Legal Studies 115

111 Article 5 of China's Companies Law (2005) states that: "In its operational activities, a company shall abide by laws and administrative regulations, observe social morals and commercial ethics, persist in honesty and good faith, accept supervision by the government and the public, and assume social responsibility. The legitimate rights and interests of companies shall be protected by law, and shall be inviolable." 
Article 19 of the 2005 Company Law requires that listed companies in China must provide the necessary conditions for the Communist Party organisation to operate and carry out its activities. ${ }^{112}$ Not only does this create a Party Committee within each Chinese company, it is often the case that the Party Secretary within a company will also hold a key position in the organisational structure of the company itself, such as that of Chairperson or General Manager. ${ }^{113}$ It is not unusual for large private companies, such as technology company Huawei, to also establish a party committee structure within the company. ${ }^{114}$ The operation of a party structure within large Chinese-controlled companies may continue to exist, even where the company leaves mainland China and where local company law requirements are different from those in China. This is the case, for example, in Hong Kong, where locally listed Chinese state-owned companies continue to have active party structures. ${ }^{115}$

Most importantly, Chinese officers employed by SOEs and their subsidiaries may also be subject to Chinese Communist Party discipline (as Party members) by the Party's Central Commission for Discipline Inspection for corrupt practices and malfeasance. ${ }^{116}$ This is likely to be more punitive than the use of any formal system of company law rules. China's ongoing anti-corruption campaign seeks to "uphold the principle that Party discipline is stricter than the law". ${ }^{117}$ The centrality of the Communist Party in China's constitutional order is well known. ${ }^{118}$

112 Article 19 of China's Companies Law (2005) provides: "In companies, Communist Party organizations shall, in accordance with the provisions of the Constitution of the Communist Party of China, be set up to carry out activities of the Party. Companies shall provide the necessary conditions for the Party organization to carry out their activities."

113 See Andrews and Tomasic, above n 86.

114 Siobhan Gorman "China Tech Giant Under Fire: Congressional Probe Says Huawei Poses National-Security Threat to the U.S." The Wall Street Journal (online ed, New York, 8 October 2012). Also see Rachel Lu and David Wertime "China Strikes Back: Defending Huawei and ZTE from Its Congressional Critics: American companies operating in the People's Republic have Communist Party committees, too" The Atlantic (online ed, Washington (DC), 10 October 2012).

115 See Flora Xiao Huang and Horace Yeung Chinese Companies in the Hong Kong Stock Market (Routledge, New York, 2014) at 224.

116 See Yongshun Cai State and Agents in China: Disciplining Government Officials (Stanford University Press, Stanford, 2015); and John P Burns (ed) The Communist Party's Nomenklatura System (ME Sharpe, New York, 1989).

117 "Bunkers, banquets and bribes: Why banning golf won't curb corruption" The Economist (online ed, Beijing, 31 October 2015).

118 See generally Q Zhang The Constitution of China: A Contextual Analysis (Hart Publishing, Oxford, 2012); Larry Catá Backer "A Constitutional Court for China within the Chinese Communist Party: Scientific Development and the Institutional Role of the CCP" (2010) 3 Suffolk U L Rev 593; and Larry Catá Backer "Crafting a Theory of Socialist Democracy for China in the 21 st Century: Considering Hu Angang's (胡鞍 钢) Theory of Collective Presidency in the Context of the Emerging Chinese Constitutional State" [2014] Asian-Pacific Law \& Policy Journal 29. 
SASAC has also issued its own CSR guidelines that apply to centrally controlled SOEs (CSOEs). ${ }^{119}$ These guidelines state that: ${ }^{120}$

Fulfilling CSR is the need for the CSOEs to participate in international economic cooperation. As [to] the progress of economic globalization, the international community concerns more and more on the performance of an enterprise in social responsibilities [sic]. By fulfilling CSR, it is either helpful in establishing a "responsible" public image by Chinese enterprises and more internationally influential, or significant for China to spread an image as a responsible nation.

SASAC went on to stress the central role of the Communist Party in this regard of: $:^{121}$

Strengthening CPC organizations' role in leading the CSR work of enterprises. The CSOEs should give full play to the political core role of the Communist Party of China (CPC) branches in the enterprise; encourage CPC members to take the lead in performing CSR.

It is unclear how effective such soft law prescriptions will be in SOEs operating outside China, although they are intended to apply to these. However, what is clear is that in regard to China's CSOEs, the Party Committee in each company is required to assume core leadership in the enterprise. ${ }^{122}$

A focus on promoting CSR principles has also been reflected in guidelines jointly issued in 2013 by China's Ministry of Commerce and the Ministry of Environmental Protection (MOFCOM). ${ }^{123}$ These urged Chinese companies investing overseas to foster sustainable development and environmental protection. This has been echoed by Chinese industry associations that have also issued their own CSR guidelines. ${ }^{124}$ The impact and effectiveness of these CSR norms and guidelines is, however, far from clear. In one European study of China's largest transnational corporations operating

119 State-owned Assets Supervision and Administration Commission of the State Council, China "Guidelines to the State-owned Enterprises Directly under the Central Government on Fulfilling Corporate Social Responsibilities" <http://en.sasac.gov.cn>.

120 At 4.

121 At 20

122 General Office of the Party's Central Committee and China's State Council "Temporary Regulations on the Implementation of Accountability of Leading Cadres" (2009). See Joseph YS Cheng (ed) China: A New Stage of Development for an Emerging Superpower (City University Press, Hong Kong, 2012) at 39.

123 Ministry of Commerce, China "MOFCOM and MEP Jointly Issued Guidance on Environmental Protection in Foreign Investment and Cooperation" (4 March 2013) <http://english.mofcom.gov〉.

124 See for example China Chamber of Commerce of Metals, Minerals \& Chemicals Importers \& Exporters Guidelines for Social Responsibility in Outbound Mining Investments (2014). 
in Europe, Sutherland and Whelan asked why these companies adopted CSR reporting and observed: ${ }^{125}$

Further analysis of the CSR reports shows that the strongest common theme running through them is the commitment to implementing government policy. This is most commonly captured in language that closely echoes that of central policy makers ... As such these stock phrases are clearly meant to signify adherence to political ideology of the CCP.

In Australia, Huang and Staples have also examined CSR practices of Chinese companies in Australia and noted: "Chinese companies in Australia have made great efforts and spent substantial resources on community engagement." ${ }^{126}$ Huang had earlier observed that: ${ }^{127}$

... putting in place a good corporate governance system is a big challenge for Chinese firms as corporate governance is a relatively new concept in China. For Chinese subsidiaries in Australia, this can be more difficult as they have to deal with the vast differences in corporate governance between China and Australia.

One way of dealing with these challenges is the appointment of officers from the Chinese parent company to the subsidiary in Australia. As Huang also noted: "Most Chinese companies in Australia have CEOs appointed from the parent company, particularly in Chinese SOEs." 128 The use and effectiveness of soft law codes calls for closer examination in the context of Chinese-controlled companies in Australia as part of a wider study of corporate governance arrangements within SOEs.

\section{Chinese SOEs' Cultural Characteristics}

The culturally embedded nature of China's corporate law practices has made the achievement of more efficient enterprises which are able to successfully coordinate complexity, something of a challenge for SOE reformers, especially where there is a need to encourage professionalism and greater autonomy of SOE employees. Redding and Witt have noted that in China, "[t]he personalized nature of many relations in the organization structure inhibits the full development of a performancebased professionalism in management and in operations." 129

125 Dylan Sutherland and Glen Whelan "Corporate Social Responsibility in China's Largest TNCs" (University of Nottingham, China Policy Institute, Discussion Paper 51, July 2009) at 13.

126 Xueli Huang and Warren Staples Community engagement by Chinese firms in Australia: practices and benefits (RMIT University, Melbourne, June 2014) at 45.

127 Xueli Huang "Corporate governance and Chinese FDI in Australia" (5 June 2011) East Asia Forum $<w w w . e a s t a s i a f o r u m . o r g>$.

128 Huang, above n 126.

129 Redding and Witt, above n 13, at 100. 
SOE reform has increasingly become a major issue in China as it has sought to establish what has been described as a "modern enterprise system" and to make SOEs both more efficient and globally competitive. However, an effort is being made to scale back the role of the state in the Chinese economy and major changes have recently been floated as China moves from a system dominated by domestic infrastructure investment and exports into a new system characterised by enhanced domestic consumption, spurring investment and creating a knowledge economy. ${ }^{130}$ The patterns of corporate governance that have evolved in China will inevitably influence the way in which Chinese executives will see the world once their companies begin to operate internationally or "go global", ${ }^{131}$ although how this will occur remains to be clarified through further research. ${ }^{132}$

Lin and Milhaupt have noted that "the predominant organizational characteristic of Chinese SOEs is groupism". ${ }^{133}$ Unlike many multinational corporations, SOEs tend not to be diversified and tend to focus upon a particular industry or sector with a parent or holding company at the core of the group. This pattern is also reflected in SOE group structures in Australia. Chinese centrally controlled SOEs operating in Australia have at least 130 subsidiaries (mostly private companies) whilst provincial SOEs have at least 84 subsidiaries. These Chinese SOEs comprise 37 of the companies on the Fortune Global 500 listing in 2015, with 33 being CSOEs. In examining the Chinese public and private company subsidiaries of SOEs currently in Australia, what is striking is the small number of public companies and the much larger number of private companies that are part of groups under the control of an SOE.

Research has shown that national cultural identity remains a core feature of corporations once they start to globalise. ${ }^{134}$ In their international study, Dine and Koutsias emphasised that "the most important conclusion of our research is that national corporate governance 'reflects public policy

130 David Shambaugh "China at the Crossroads: Ten Major Reform Challenges" (George Washington University, Research Paper, 1 October 2014) at 3.

131 See generally Roman Tomasic "Corporate Governance in Chinese Companies Going Global" (2014) 2 Chinese Journal of Comparative Law 155.

132 See generally Xueli Huang and Ian Austin Chinese Investment in Australia: Unique Insights from the Mining Industry (Palgrave Macmillan, New York, 2011).

133 Li-Wen Lin and Curtis J Milhaupt "We are the (National) Champions: Understanding the Mechanisms of State Capitalism in China" (2013) 65 Stan L Rev 697 at 712. This is to be distinguished from the phenomenon of Chinese SOEs moving "in packs" as they invest outside China. Scissors has noted: "Chinese firms have moved overseas in packs. Australia was the first destination, followed by sub-Saharan Africa, South America and, beginning in 2012, North America": Derek Scissors "Chinese Investment in the U.S.: Facts and Motives" (9 May 2013) The Heritage Foundation <www.heritage.org>.

134 Dine and Koutsias, above n 25. 
choices"'. ${ }^{135}$ In the United States, this "path dependency" effect has been a product of the political determinants of corporate governance. ${ }^{136}$

To some extent, Chinese government policies have encouraged its SOEs to list on foreign stock exchanges to enhance their corporate governance practices. ${ }^{137}$ This has been described as a "bonding effect" in that listing on a stock market in a developed economy may provide reputational advantages and improve corporate governance, such as through the appointment of independent directors. However, the effectiveness of such a bonding effect has been challenged ${ }^{138}$ and has not been empirically tested. In regard to Hong Kong, Meng has argued that the introduction of independent directors onto the boards of Chinese-listed companies has failed as it has not addressed the key agency problem that exists between the majority state shareholder and minority shareholders. ${ }^{139}$

The modest effect of foreign listing on corporate governance practices in Chinese companies was more fully explored by de Jonge in her study of the corporate governance practices of the first nine Chinese companies to list on the Hong Kong Stock Exchange between 1993 and 1994. ${ }^{140}$ In China, the central role of the state is a key factor in explaining the conduct and regulation of companies, especially SOEs. ${ }^{141}$ Not surprisingly, it is not unusual to see references in the literature to the socalled unique character of Chinese corporate governance practices. ${ }^{142}$ This can be traced back to Deng Xiaoping's call for a system of "socialism with Chinese characteristics". ${ }^{143}$

\section{SOME CONCLUSIONS}

There is clearly a need for further research into the issues raised in this article. The primary focus of this article has been upon the distinctive legal culture of Chinese SOEs at a time when such

\section{At 315 .}

136 Roe, above n 68. See also Guanghua Yu "Path dependence and interconnected institutions: Implications for legal transplantation" (2015) 30 Aust Jnl of Corp Law 177.

137 Fanpeng Meng "A history of Chinese Companies Listing in Hong Kong and its Implications for the Future" (2011) 11 JCLS 243 at 264.

138 Amir N Licht "Cross-Listing and Corporate Governance: Bonding or Avoiding" (2003) 4 Chicago Journal of International Law 141; and Amir N Licht "Legal Plug-ins: Cultural Distance, Cross-Listing and Corporate Governance Reform" (2004) 22 Berkeley Journal of International Law 195.

139 Fanpeng Meng "Legal vs Reputational Bonding: Board independence of Chinese companies listed in Hong Kong" (2013) 27 Aust Jnl of Corp Law 319.

140 de Jonge, above $n 71$.

141 See generally Iain McNeil "Adaptation and Convergence in Corporate Governance: The Case of Chinese Listed Companies" (2002) 2 JCLS 289; and Tomasic, above n 98.

142 Liu, Atinc and Kroll, above n 70.

143 Deng Xiaoping "Building Socialism with a Specifically Chinese Character" The People's Daily (online ed, Beijing, 30 June 1984) 
enterprises have become increasingly active in investing in Australia. There has been an ongoing, and somewhat inadequate, public policy debate in Australia over the nature of Chinese SOEs. This issue has become more urgent following CHAFTA.

The article has sought to explore how the Australian legal system, and Australian corporate governance practices, may change as a result of the entry of these powerful new economic actors into the Australian landscape. This calls for a mapping of the emerging legal landscape and in this regard, in Part II, the article has referred to various theoretical debates about mapping legal landscapes. This article examined some of the contours of Chinese outbound investment as illustrated by different attitudes evident in public policy, business, media and judicial commentaries on Chinese SOEs.

The article has presented data on the nature and extent of SOE investment in Australia and sought to assess the likely impact of these SOEs based on the nature of Chinese firms that have been active. Tables 1 and 2 listed the names, industry sector and global significance of Chinese SOEs, as well as the number of subsidiaries that they have operating in Australia. A total of 39 centrally controlled Chinese SOEs were identified, as well as 27 provincially controlled Chinese SOEs. It was noted that 38 of these SOEs are included in the Fortune Global 500 list of companies; by way of comparison, the article lists the eight Australian companies on the same Fortune listing.

As authorities such as Mark Roe and others have pointed out, it is well established that national corporate governance regimes are politically determined and are an expression of negotiations and practices that have developed in each country. It is also well established that the culture of multinationals, especially large state-owned companies, also reflects national characteristics, as scholars such as Dine and Koutsias have reminded us. ${ }^{144}$ These characteristics do not change dramatically when companies go abroad from their home markets.

The large body of international research on the Chinese legal system and its impact on Chinese companies has pointed to the distinctive features of Chinese corporate governance practices and corporate cultures; state-owned companies are especially prone to reflect these characteristics. The article notes that China's system of "authoritarian capitalism", as Witt and Redding describe it, has created a model of corporate governance that needs to be distinguished from the various shareholdercontrolled models that are to be found in Australia and other Western legal systems. The dominant role of the Communist Party within Chinese companies, particularly SOEs, has significant implications for the role of the board and minority shareholder protection. At the same time, large Chinese companies also have important strategic goals that distinguish them from non-state controlled companies.

Whilst Chinese SOEs have been shaped by Chinese company law and company regulation, they are also increasingly subject to CSR norms or soft laws that have been developed in China. These soft 
law norms are likely to play an increasingly important role in approaches to the governance of SOEs that have sought to internationalise and are active in Australia, as it is hard for these SOEs to lose their group character. The article explores some of these developments. The "groupism" of Chinese SOEs, as Lin and Milhaupt have described it, ${ }^{145}$ will no doubt have an effect upon disseminating governance norms within Chinese government controlled SOEs that are active in Australia.

145 Lin and Milhaupt, above n 133, at 712-716. 